\title{
Business model \\ of the enterprise \\ as a tool of building \\ interorganizational \\ relationships
}

PhD Eng. Wiesław Danielak University of Zielona Góra Faculty of Economics and Management Department of Strategic Management and Marketing

\section{Introduction}

A business activity is related to numerous connections and interdependences the entities, such as enterprises, suppliers, customers, business-related institutions or competitors establish due to the economic activity they run. The present reality is characterized by complexity and diversity of factors influencing the relationships of cooperation. These relationships stay in a close connection with a business model whose elements are people (employees, owners, suppliers, customers) as well as structures, processes and relationships the enterprises create with the environment. The increase of the interest in interorganizational relationships results from the growth of relationships paradigm, which refers to all activities associated with establishing, developing and maintaining a successful relational exchange (Morgan, Hunt 1994, p. 20-38). The relationships paradigm gains in importance due to changes taking place in the environment of enterprises, which must adapt to or predict changes constantly in order to realize their goals.

The aim of the article is to present the essence of the business model of the enterprise 
as a tool of building interorganizational relationships. The paper defines the notion of a business model, indicates the components of relational exchange between a customer and a supplier as well as describes the elements of the model of interorganizational relationships.

\section{The essence of the business model of the enterprise}

Both in the theory and practice there are a number of definitions presenting the essence of the business model of the enterprise.

According to T. Gołębiowski and others $(2008$, p. 57) a business model is a set of components and relationships between them, which presents the logic of a particular enterprise operation in a particular branch. It includes the description of values offered by the enterprise to a group or groups of customers, together with defining basic assets, processes (actions), and also external relationships of the enterprise aiming at creating values and providing competitiveness for the enterprise in a particular area as well as enabling the increase of its value. Therefore, the conception of a business model proves that it is a tool allowing to use internal potential in favour of fulfilling the environment needs. Business models allow to describe how assets are linked and transformed in order to generate values for customers and other interested sides (Magretta 2002, p. 8692, quoted after: Wikström and others 2010, p. 834).

According to J. Galbraith a business model "expresses the internal logic of running a business and includes the manner of understanding basic business values, target market segments, channels of distribution, cost structure and return on the investment model (Kotes, Galbraith 2007, p. 6, quoted after: Bełz 2011, p. 16.)

The research of Wikström and others (2010, p. 835) proves that business models are most often treated by management as the way of organizing the enterprise activity, the aggregation of possibilities and integration of business actions with external partners. It is connected with the ability of establishing relationships with the social environment, care about proper communication and clear information concerning the vision, mission and strategies of the organization in such a way as the coupling of goals and activities on its all levels takes place" (Miziołek 2010, p. 109).

In the conditions of the environment changes the maintenance of relationships with customers (suppliers) is indispensible, whose manifestation is the orientation to customer (supplier), which makes better communication and responding to customer (supplier) needs easier. A supplier aims at obtaining 
benefits from selling their products, gaining dues on time, stability of deliveries or satisfaction from cooperation. A purchaser, however, is interested in buying at low cost a high quality product quickly and on time.

In practice there are a number of factors determining the exchange between a purchaser and supplier, which according to J. Thakkar, A. Kand, S.D. Deshmukh (2008, p. 95) are the factors: determining cooperation (culture, trust, reciprocity, communication, information exchange), maintaining cooperation (involvement, support), helping achieve success (change management, interdisciplinary activity, adaptation processes), referring to the means of operation, incurred cost as well as possible failures resulting from partner's behaviour or changes on the market (figure 1).

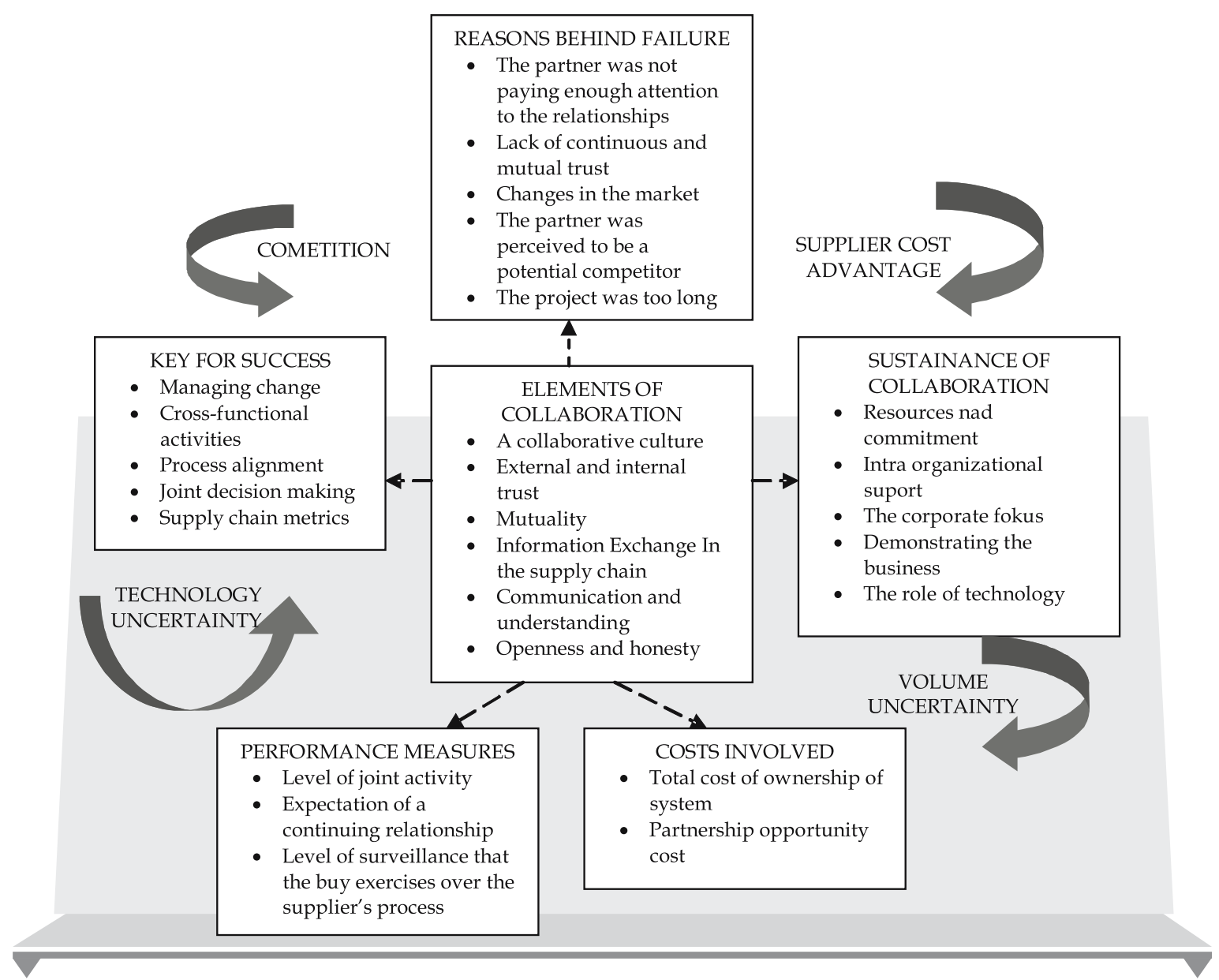

Figure 1. Components of buyer-supplier environment and relationships

Source: Thakkar J., Kanda A., Deshmukh S.D., 2008, s. 95

Business model of the enterprise as a tool of building interorganizational relationships 
What allows to build business models is the elements including (cf. Marti 2001, p. 154-155):

- products/services,

- architecture of basic and supportive actions (outsourcing),

- alliances: strategic, franchising networks, cooperation agreements,

- competitive advantage,

- research, development and innovation,

- elementary competences,

- culture: success based on cultural patterns,

- managing and professional leadership.

Moreover, business models should be properly adjusted to particular strategies, structures, culture and leadership roles. A business model of the company can be a source of competitive advantage (Wikström and others 2010, p. 834). Being more competitive on the market is not easy to achieve at all, however, it requires work over improving a present offer of products and services as well as introducing innovative solutions, gaining new knowledge and new competences. It all takes place with the participation of an entrepreneur and managing staff, who change values, rules and principles of operating in order to meet the environment needs and build relationships based on stable forms of cooperation.

According to S. Nenonen and K. Storbacka (2010, p. 45), despite the existence of many definitions of business models, it is possible to point out some similarities. A part of them is related to economic categories (revenue, income), possibilities of generating a profit. The other ones refer to external stakeholders or partner relationships. A big part of them also refers to the assets and possibilities of the company. However, a majority of definitions focuses on creating values for the enterprise, customer and supplier indicating the way the enterprise having a particular technology, assets and possibilities can configure the structure of the organization and relationships with external entities to make them favourable for the exchange of products and information.

\section{The elements of the model of interorganizational relationships}

The changeability of the conditions of enterprises operation influences the increase of the intensity of business relationships. Enterprises make efforts in favour of creating profitable relationships with entities in the environment. Building the enterprise relationships with entities in the environment heads towards creating interorganizational links, which are a special type of impacts between two or a bigger number of enterprises, where there is the information, 
material or energetic exchange, whereas the sides of the exchange show involvement and this attitude is mutual (Czakon 2007, p. 9).

Relationships become the stronger the bigger number of employees contact or cooperate with customers (suppliers) in issues essential for both sides (Ulrich 2008 , p. 106). If both sides head for building relationships and their impacts are very positive, thus the relationship will develop quickly and efficiently (Biggemann 2010, p. 181).

The process of creating and developing a relationship can be analyzed through factors, which influence the relationships in different stages of their life cycle. According to T.L. Powers and W.R. Reagan (2007, p. 1235), it is possible to distinguish five stages of a relationship development including: selection of a partner, defining goals of a relationship, determining borders of a relationship, creating values and maintaining a relationship. The analysis of particular stages allows to trace activities supporting building a relationship as well as evaluate the obtained benefits and incurred cost.

In order to present a complex nature of interorganizational relationships in this paper a model of interorganizational relationships elaborated by Croteau A.M., Léger P.M., Cassivia L. (2008, p. 145-161) was used. These researchers distinguished two areas in their model allowing to create interorganizational relationships. The first one concerns proper adjustment of relationship sides to the demand for processing information, the second one, however, is connected with the possibilities of processing information (figure 2).

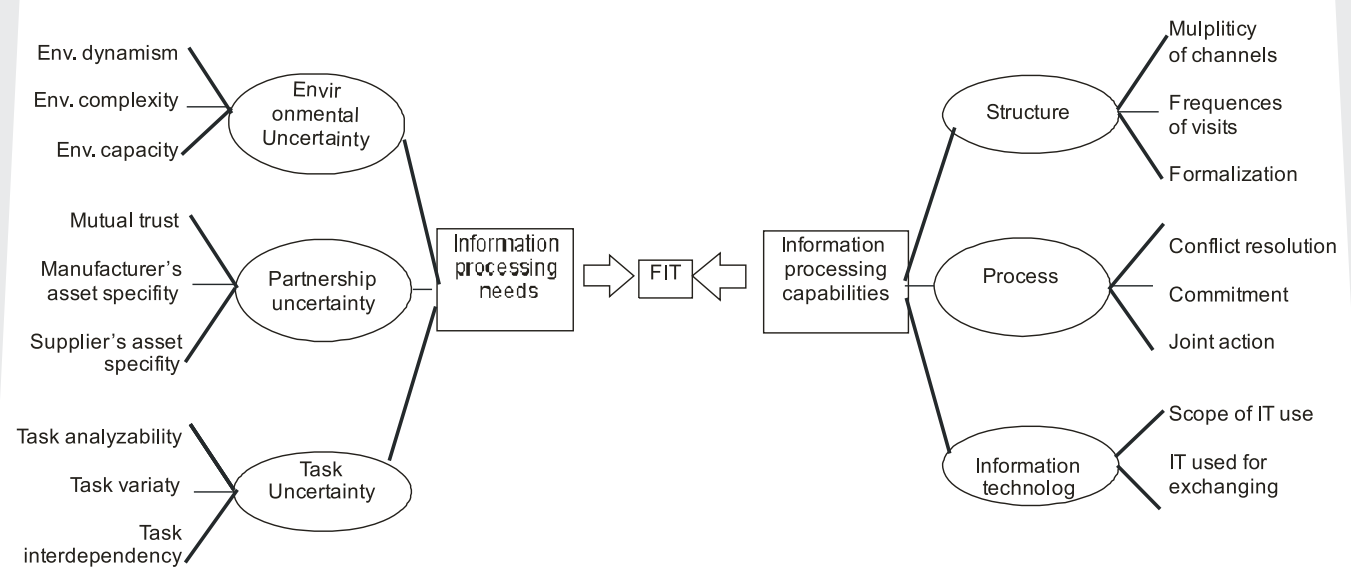

Figure 2. Model of interorganizational relatonships

Source: Croteau A.M., Léger P.M., Cassivi L. 2008, s. 148 
Due to the fact that the needs for processing information are being developed in the context of uncertainty, where economic processes develop, the analysis includes three types of uncertainty: environment uncertainty (complexity, character and dynamics of relationships), partnership uncertainty (perception of mutual trust, specificity of possessed assets) and tasks uncertainty (diversity of tasks, cooperation procedures). However, the second area is connected with the possibilities of processing information, which requires the ability of coordination within three dimensions of: structural solutions (plurality and formalization of interorganizational relationships), solutions in the sphere of processes (social-political processes, solving conflicts, common actions) and solutions in the sphere of information technology, i.e. using IT in the process of data and information exchange between involved sides.

Relationships created in order to solve a particular problem or use a chance in a short-term perspective seem to differ a lot from these ones whose character is long-term. The length of a mutual exchange is perceived to be the possibility of creating strong and durable relationships. The undertaken actions are usually time-consuming, require involvement, active cooperation and skills of solving mutually problems. The essence of long-term relationships proves that the relationship is important for the enterprise, and that the enterprise is open to new possibilities of building relationships (cf. Jarratt 2008, p. 1114). Despite a number of advantages of long-term relationships, it is possible to point out their defects as well (table 1).

The undertaken actions in the sphere of developing and maintaining stable, long-term relationships require bigger involvement of sides and improvement of solutions in the area of a business model, which would include long-term relationships.

\section{Tabela 1. Advantages and Disadvantages of Developing and Managing Long-term Relationship between Buyers and Suppliers}

\begin{tabular}{l|l}
\hline \multicolumn{1}{c|}{ Advantages } & \multicolumn{1}{c}{ Disadvantages } \\
\hline $\begin{array}{l}\text { Better understanding of needs and requirements of } \\
\text { partners (Kalwani and Nayarandas 1995) }\end{array}$ & $\begin{array}{l}\text { Increased dependence leading to increased } \\
\text { switching costs and increased barrier to } \\
\text { exit (Kalwani and Nayarandas 1995) }\end{array}$ \\
\hline $\begin{array}{l}\text { Reduced transaction costs: appropriation and } \\
\text { monitoring costs and reduced relationship and } \\
\text { environmental uncertainty (Andersson et al. 2002; } \\
\text { Gundlach et al. 1995) }\end{array}$ & $\begin{array}{l}\text { Reduced flexibility to access other partners } \\
\text { (Kalwani and Nayarandas 1995) }\end{array}$ \\
\hline
\end{tabular}


Access to knowledge and information and opportunity to learn from one another (Andersson et al. 2002; Kalwani and Nayarandas 1995; Landeros et al. 1995)

Bilateral governance and safeguarding mechanism, especially crucial due to intellectual property (Heide and John 1990)

Strengthen competitive position by improving quality, productivity, delivery, technology, processes, etc. (Cannon and Homburg 2001; Heide and John 1990; Kalwani and Nayarandas 1995; Landers et al. 1995)
Knowledge spillover resulting in overstepping intellectual property boundaries

Unable to reduce uncertainty effectively

Source: Khoja, Adams, Kauffman 2010, s. 291

Stable relationships give a sense of safety and certainty as well as the perspective of long-term cooperation. A complex and dynamic nature of relationships has an impact on the process of evaluating relationships by involved entities. These are them who identifies variables and make decisions connected not only with initiating, maintaining, investing, but also with terminating a relationship. In the conditions of change management a business model is also assessed and modified.

\section{Conclusion}

Business models present the manner of running the economic activity, fulfilling the environment needs. They help build interorganizational relationships, which based on skills of establishing, maintaining and developing relationships with entities in the environment.

A business model shows relationships and obligations between purchasers and suppliers including the environment conditions. For example in case of appearing a crisis there can be an increase or fall of the involvement of sides. A business model also has to take into consideration management infrastructure consisting of organizational structure, strategies, methods, processes and their regulation as well as intellectual capital (Skalik 2011, p. 9). The length of a relationship duration can be connected with a business model as well. While realizing investments requiring substantial outlays it seems to be significant to build long-term relationships including changes in the sphere of structures, processes or information technology. 


\section{Summary}

Keywards: business model, relational exchange, interorganizational relationships,

Business model of the enterprise as a tool of building interorganizational relationships

The deliberations included in the article concentrate on the essence of the business model of the enterprise as a tool of building interorganizational relationships. The importance of interorganizational relationships has been indicated, the ones, which stay in a close connection with the business model whose elements are people (employees, owners, suppliers, customers) as well as structures, processes and relationships the enterprise establishes with the environment. The elaboration defines the notion of a business model, presents the components of relational exchange between a purchaser and supplier as well as characterizes the elements of interorganizational relationships model.

\section{Streszczenie}

Słowa

kluczowe: model biznesowy, wymiana relacyjna, relacje międzyorganizacyjne

\section{References}

1. Andersson U., Forsgren M., Holm U. (2002), The strategic impact of external networks: Subsidiary performance and competence development in the multinational corporation, "Strategic Management Journal", vol. 23. 
2. Bełz G. (2011), System zarzadzania jako regulator odnowy $i$ wzrostu przedsiębiorstw, Wydawnictwo Uniwersytetu Ekonomicznego we Wrocławiu, Wrocław.

3. Biggemann S. (2010), Understanding and modeling the dynamics of business-tobusiness relationships, "Advances in Business Marketing and Purchasing" vol. 16.

4. Cannon J., Homburg C. (2001), Buyer-supplier relationships customer assets, "Journal of Marketing", vol. 65.

5. Croteau A.M., Léger P.M., Cassivi L. (2008), The role of life cycle concepts in the assessment of interorganizational alignment, "Industrial Management \& Data Systems", vol. 108, no. 2.

6. Czakon W. (2007), Dynamika więzi międzyorganizacyjnych przedsiębiorstwa, Prace Naukowe Akademii Ekonomicznej w Katowicach im. Karola Adamieckiego, Katowice.

7. Dampérat M.,Jolibert A. (2009), A dialectical model ofbuyer-seller relationships, "Journal of Business \& Industrial Marketing", vol. 24, no. 3/4.

8. Gołębiowski T., Dudzik T.M., Lewandowska M., Witek-Hajduk M. (2008), Modele biznesu polskich przedsiębiorstw, Szkoła Główna Handlowa, Warszawa.

9. Gundlach G., Achrol R., Mentzer J. (1995), The structure of commitment in exchange, "Journal of Marketing", vol. 59, no 1.

10. Heide J., John G. (1990), Alliances in industrial purchasing the determinates of joint actions in buyer-supplier relationships, "Journal of Marketing Research", vol. 27.

11. Jarratt D. (2008), Testing a theoretically constructed relationship management capability, "European Journal of Marketing", vol. 42, no. 9/10.

12. Kalwani M., Narayandas N. (1995), Long-term manufacturer-supplier relationships: Do they pay off for supplier firms? "Journal of Marketing", vol. 59, no. 1.

13. Khoja F., Adams J., Kauffman R. (2010), A Temporal Model of Vertical Relationships, "Journal of Business-to-Business Marketing", vol. 17, no 3.

14. Landeros R., Reech R., Plank R.(1995), Maintaining buyer-supplierpartnership, "International Journal of Purchasing and Materials Management".

15. Marti J.M.V. (2001), ICBS - intellectual capital benchmarking system, "Journal of Intellectual Capital", vol. 2, no. 2.

16. Miziołek K. (2010), Kwalitatywne oceny naczelnego kierownictwa przedsiębiorstwa - wybrane zagadnienia, Zeszyt Naukowy nr 100, Szkoła Główna Handlowa, Warszawa.

17. Morgan, R.M., Hunt, S.D. (1994), The commitment-trust theory of relationship marketing, "Journal of Marketing", vol. 58, no. 3.

18. Nenonen S., Storbacka K. (2010), Business model design: conceptualizing networked value co-creation, "International Journal of Quality and Service Sciences", vol. 2, no. 1. 
19. Powers T. L., Reagan W. R. (2007), Factors influencing successful buyer-seller relationships, "Journal of Business Research", vol. 60, no. 2.

20. Skalik J. (2011), Organizational potential and its influence on the growth and development of the company, "Management”, vol. 15, no. 1.

21. Thakkar J., Kanda A., Deshmukh S.D. (2008), Evaluation of buyer-supplier relationships using an integrated mathematical approach of interpretive structural modeling (ISM) and graph theoretic matrix. The case study of Indian automotive SMEs, "Journal of Manufacturing Technology Management", vol. 19, no. 1.

22. Wikström K., Artto K., Kujala J., Söderlund J. (2010), Business models in project business, "International Journal of Project Management", vol. 28, no. 8 . 